\title{
EFEKTIVITAS MODIFIED COLABORATIVE STRATEGIC READING DALAM READING CLASS ACTIVITY
}

\author{
Putu Ayu Paramita Dharmayanti, Dewa Ayu Ari Wiryadi Joni \\ Program Studi Pendidikan Bahasa Inggris \\ Fakultas Keguruan dan Ilmu Pendidikan \\ Universitas Mahasaraswati Denpasar
}

\begin{abstract}
The study aimed at improving the students' reading comprehension by implementing Modified Collaborative Strategic Reading (MCSR) technique. The subject was grade eleven students of SMA (SLUA) Saraswati 1 Denpasar, in which the amount was thirty students. There were two cycles (eight meetings), in this Classroom based Action Research. There were three instruments used: test, questionnaire, and diary. From the result of the post-test and analyzed questionnaire, it is shown that there is an increase in every meeting. This can be concluded that MCSR is effective in improving the students' reading comprehension.
\end{abstract}

Keywords: MCSR, reading comprehension 


\section{PENDAHULUAN}

Membaca adalah alat untuk memperluas pengetahuan pembaca dan membantu pembaca untuk berkomunikasi dengan orang lain. Mengingat betapa pentingnya kegiatan membaca, pengajaran membaca harus diberikan perhatian yang lebih intensif.

Berdasarkan pengamatan yang dilakukan oleh peneliti di kelas XI LAB SMA (SLUA) Saraswati 1 Denpasar, diketahui bahwa nilai pelajaran reading tidak terlalu memuaskan. Hal ini disebabkan oleh metode pembelajaran reading yang diterapkan guru di kelas tersebut masih bersifat tradisional yakni guru hanya meminta siswa untuk membaca text tanpa pemahaman lebih jauh dan hanya mementikan kebenaran dalam mengucapkan kata (bahasa inggris). Melalui wawancara singkat terhadap beberapa siswa, diketahui bahwa sebagian besar siswa merasa matakuliah reading membosankan dan cara pengajarannya pun kurang menarik.

Salah satu metode pembelajaran yang dapat digunakan untuk meningkatkan kemampuan membaca siswa adalah MCSR. Modifikasi Membaca Strategis Collaboratif (MCSR) adalah versi modifikasi dari Reading Strategis Collaboratif (CSR).

Alasan memodifikasi CSR adalah untuk menawarkan strategi membaca yang lebih tepat. Zoghi et al. (2006) mendefinisikan bahwa CSR dibatasi oleh kisaran sempit strategi membaca seperti mengaktifkan pengetahuan sebelumnya, meringkas ide utama, dan merumuskan pertanyaan. Teori-teori yang mendasari dari MCSR adalah teori interaktif, kognitif - konstruktivis, dan perspektif konstruktivisme sosial.

Implementasi MCSR berlangsung dalam tiga tahap, yang secara tradisional disebut sebagai presentasi, praktek, dan tahap produksi. Adapun empat strategi yang diterapkan yaitu (a) preview strategy, (b) fix-up strategy, (c) get-the-gist strategy, and (d) wrap-up strategy.

Dengan preview strategy, siswa melakukan 2 kegiatan: brainstorming and predicting. Tujuan preview strategy adalah mengaktifkan latar belakang pengetahuan siswa tentang topik, membantu siswa untuk memprediksi tentang apa yang mereka akan mereka baca dan memotivasi minat siswa untuk membaca teks.

Pada fix-up strategy, siswa terlibat dalam pembelajaran kooperatif. Instruktur meminta siswa untuk membentuk kelompok-kelompok kecil dengan lima anggota di setiap kelompoknya. Siswa kemudian diminta untuk membaca bahan bacaan yang dipilih sementara mereka bertindak sesuai peran yang telah ditentukan:

1. Pemimpin: Memimpin kelompok dengan mengatakan strategi apa yang harus diterapkan selanjutnya;

2. Monitor: memastikan semua orang dalam kelompok berpartisipasi;

3. Fix-up pro: memonitor pemahaman bacaan kelompok;

4. Encourager: memantau kelompok dan memberikan umpan balik;

5. Reader: Memiliki tanggung jawab membaca.

Dalam menggunakan fix-up strategy siswa diharapkan untuk: (a) membaca ulang kalimat untuk menentukan kata yang tidak dikenal, (b) mencari akhiran dalam kata yang tidak dikenal, (c) memecahkan kata yang tidak dikenal, (d) mengidentifikasi struktur teks, dan (e) mengidentifikasi kata-kata penghubung.

Pada langkah berikutnya, siswa beralih untuk menggunakan get-the -gist strategy dimana siswa terlibat dalam proses mengidentifikasi ide pokok, kalimat utama, dan informasi spesifik di bagian teks. Tujuan get-the-gist strategy adalah meningkatkan memori siswa tentang apa yang telah mereka baca sehingga mereka dapat menyajikan kembali hal paling penting dengan menggunakan kata-kata mereka sendiri sebagai cara untuk memastikan mereka telah memahami apa yang telah mereka baca.

Dengan menggunakan wrap-up strategy, instruktur meminta siswa untuk melakukan kegiatan-kegiatan berikut dalam kelompok mereka setelah seluruh teks dibaca: menghasilkan pertanyaan untuk mewawancarai satu sama lain, menceritakan kembali apa yang telah dibaca berupa ringkasan; dan melakukan perdebatan pro- kontra tentang topic.tujuan wrap-up strategy adalah untuk 
meningkatkan pengetahuan, pemahaman, dan memori dari apa yang dibaca siswa.

\section{METODOLOGI PENELITIAN}

Subjek penelitian adalah siswa kelas XI LAB SMA (SLUA) Saraswati 1 pada tahun ajaran 2013/2014 dengan jumlah siswa dalam kelas penelitian adalah 30 siswa.

Penelitian yang dilakukan adalah Penelitian Tindakan Kelas (PTK) / Classroom Action Research (CAR). Penelitian ini termasuk kedalam Penelitian Tindakan Kelas karena peneliti berupaya untuk meningkatkan kinerjanya dalam mengajar untuk meningkatkan kemampuan siswa melalui serangkaian tindakan dalam proses belajar mengajar.

PTK merupakan proses pengkajian suatu masalah pada suatu keals melalui siklus daur ulang dari berbagai kegiatan yang pada pokoknya terdiri dari empat tahapan, yaitu perencanaan (planning), implementasi tindakan (implementation of the action), pengamatan (observation) dan refleksi (reflection).

Instrument yang digunakan untuk pengumpulan data dalam penelitian ini adalah: tes, kuisioner, dan diari. Data yang diperoleh kemudian dianalisis bersama untuk mendapatkan prosentase yang menggambarkan peningkatan pada kemampuan membaca siswa setelah diberi tindakan.

\section{ANALISIS DATA DAN PEMBAHASAN}

Sebelum melakukan penelitian di dalam kelas, tim peneliti mengadakan rapat teknis guna membicarakan persiapan yang perlu dilakukan sebelum terjun meneliti. Setelah itu peneliti membahas silabus serta materi-materi yang akan diajarkan. Sumber ajar yang dipakai bukan hanya diambil dari buku yang sudah tersedia atau yang dipakai oleh guru pengempu mata kuliah tetapi juga diambil dari sumber lainnya seperti buku luaran dan internet.

Setelah mendiskusikan isi silabus dan menentukan materi yang akan diajarkan, tim peneliti bersama-sama merancang bahan ajar.
Bahan ajar dalam penelitian ini berupa teks deskriptif dan ekspositori sesuai dengan materi ajar reading di semester dua. Selanjutnya, tim peneliti merancang SAP (Satuan Acara Perkuliahan). SAP yang dirancang merupakan SAP untuk dua siklus: dimana terdapat delapan kali pertemuan.

Tahapan selanjutnya adalah pembuatan soal dan kuisioner. Post-test dalam penelitian ini di lakukan di setiap akhir pertemuan. Oleh karena itu, tim peneliti menyusun soal untuk delapan kali. Satu kali post-test berisikan 10 butir soal dimana soal tersebut berupa multiple-choice test. Kuisioner yang disusun pun terdiri dari 10 butir pertanyaan yang berkenaan dengan metode yang digunakan dalam proses pembelajaran. Tahapan terakhir dalam persiapan penelitian adalah pengadaan sarana dan media ajar seperti alat tulis dan LCD.

Penelitian ini telah dilaksanakan dalam delapan pertemuan. Dalam pelaksanaannya, tatap muka di dalam kelas dilaksanakan sekali dalam seminggu yang dimulai dari awal bulan mei sampai dengan awal bulan juli. Penelitian ini dilaksanakan di kelas XI dengan jumlah siswa sebanyak 30 orang.

Selama proses penelitian berlangsung, kemampuan membaca siswa perlahan-lahan meningkat. Sampai pada pertemuan di akhir siklus dua, nilai post-test siswa menunjukan peningkatan yang signifikan. Hal ini menjadi pertimbangan tim peneliti untuk hanya melakukan penelitian dalam dua siklus saja.

Setelah pertemuan terakhir di siklus dua berakhir, siswa diminta untuk menjawab beberapa pertanyaan yang terdapat di dalam kuisioner yang telah dibuat oleh tim peneliti.

Data yang diperoleh berupa nilai post-test dan hasil kuisioner akan dianalisis sehingga dapat mengungkapkan tingkat kemajuan subyek dalam kemampuan membaca bahasa Inggris serta respon mereka terhadap pengajaran membaca dalam mata pelajaran Bahasa Inggris di kelas menggunakan strategi MCSR. Ada pun hasil nilai rata-rata post test setiap pertemuan sebagai berikut: 
TABEL 1. Ringkasan Nilai Rata-rata Post-Test Tiap Petemuan dan Tiap Siklus

\begin{tabular}{cccc}
\hline Siklus & Post-test ke- & Nilai post-test & Total \\
\hline & $\mathrm{X} 1$ & $=5.1$ & \\
$\mathrm{X} 2$ & $=5.8$ & 6 \\
$\mathrm{I}$ & $\mathrm{X} 3$ & $=6.3$ & \\
& $\mathrm{X} 4$ & $=6.7$ & \\
& $\mathrm{X} 5$ & $=7$ & 7.8 \\
$\mathrm{X} 6$ & $=7.4$ & \\
$\mathrm{X} 7$ & $=7.7$ & \\
$\mathrm{II}$ & $\mathrm{X} 8$ & $=8.1$ & \\
& &
\end{tabular}

Dari hasil analisis data di atas dapat dilihat bahwa nilai membaca di setiap pertemuan makin meningkat. ada pun nilai rata-rata siswa di siklus pertama secara berturut-turut adalah $5.1 ; 5.8 ; 6.3$; dan 6.7. Meski pun sudah terlihat ada peningkatan tapi peneliti merasa peningkatannya belum terlalu signifikan sehingga diadakanlah siklus kedua. Ada pun nilai rata-rata siswa di siklus kedua secara berturut-turut adalah 7; 7.4; 7.7; and 8.1. Dari ratarata siklus pertama dan siklus kedua dapat dilihat adanya perbedaan dimana rata-rata siklus ke dua jauh lebih tinggi dibandingkan siklus pertama yaitu $\mathrm{C} 1=6$ dan $\mathrm{C} 2=7.8 . \quad$ Dari hasil tersebut dapat disimpulkan bahwa pengajaran membaca dalam bahasa Inggris menggunakan teknik MCSR dapat meningkatkan kemampuan membaca siswa.

MCSR. Modifikasi Membaca Strategis Collaborative (MCSR) adalah versi modifikasi dari Reading Strategis Collaborative (CSR) yang merupakan salah satu strategi membaca yang menggabungkan pembelajaran kooperatif dengan strategi pemahaman bacaan (Zoghi, et.al: 2006). MCSR menggabungkan empat strategi pemahaman bacaan yang terdapat dalam CSR, yaitu, (a) preview strategy, (b) fix-up strategy, (c) get-the-gist strategy, and (d) wrap-up strategy dimana implementasinya berlangsung dalam tiga tahap, yang secara tradisional disebut sebagai tahap presentasi, tahap praktek, dan tahap produksi.

Dalam implementasi nyata dari MCSR di kelas, perlahan parasiswa bisa memahami teks dengan benar. Dalam pertemuan pertama yang diselenggarakan pada 9 Agustus 2013, strategi MCSR diperkenalkan kepada siswa dengan menjelaskan dan berlatih, sehingga mereka bisa mengerti bagaimana MCSR dilakukan. MCSR diajarkan secara metakognitif dengan prinsip perencanaan, pemantauan diri, dan evaluasi. Hal ini didukung oleh Elkaumy (2004) yang mendefinisikan strategi metakognitif dalam tiga cara: Perencanaan, self-monitoring dan evaluasi atau berpikir tentang berpikir. Perencanaan adalah memiliki tujuan membaca dalam pikiran untuk membaca teks agar lebih selektif dan fokus pada informasi yang diinginkan. Pemantauan diri adalah mengatur proses membaca dan menggunakan strategi pada waktu yang tepat. Mengevaluasi adalah mengetahui apakah tujuan tercapai atau tidak. Sehubungan dengan menggunakan strategi pada waktu yang tepat, MCSR menggunakan strategi membaca kognitif dalam bentuk preview strategy, fix-up strategy, get-the-gist strategy, and wrap-up strategy.

Tujuan preview strategy adalah mengaktifkan latar belakang pengetahuan siswa tentang topik, membantu siswa untuk memprediksi tentang apa yang akan mereka baca dan memotivasi minat siswa untuk membaca teks. Dalam kenyataannya di kelas, siswa sangat aktif terlibat dalam tahap ini. Siswa sangat termotivasi untuk membagi pengetahuan mereka tentang topic bacaan yang akan mereka baca. Beberapa dari mereka bahkan memberikan pengalaman pribadi tentang topic tersebut. Dalam menjelaskan kata-kata tidak jelas, frasa, atau kalimat, siswa menggunakan fix-up strategy dalam bentuk beberapa kegiatan seperti membaca kalimat untuk menentukan kata yang tidak dikenal, membaca ulang kalimat sebelum dan sesudah kata yang sulit untuk mencari petunjuk, dan mencari awalan atau akhiran dalam kata yang tidak dikenal. Sementara menggunakan fix-up strategy, siswa yang memiliki penguasaan kosakata yang kurang tetap pasif karena mereka tidak merasa yakin dengan sedikitnya jumlah kosakata yang mereka 
miliki. Berdasarkan pengamatan yang digelar di pertemuan kedua, siswa yang memiliki penguasaan kosakata yang baik mulai menyadari peran mereka sebagai pembantu bagi siswa yang memiliki penguasaan kosakata yang kurang.

Dengan menggunakan fix-up strategy, siswa yang memiliki penguasaan kosakata yang baik mampu meningkatkan kualitas kosa kata mereka. Jika awalnya mereka hanya tahu satu arti dari sebuah kata, sekarang mereka tahu beberapa arti dari sebuah kata berdasarkan konteks kalimat serta pengetahuan lainnya dari kata sebagai kelas kata, imbuhan, akar, antonim dan sinonim. Namun, siswa yang memiliki penguasaan kosakata yang kurang baik sangat terbantu dengan fix-up strategy dalam membuat arti sebuah kata dalam teks. Sehingga mereka dapat memahami teks secara keseluruhan. Akibatnya, mereka tidak mengalami banyak kesulitan dalam menemukan gagasan utama atau informasi spesifik yang terkandung dalam teks yang mereka baca dengan menggunakan get-the-gist strategy. Dalam strategi ini siswa terlibat dalam proses mengidentifikasi ide pokok, kalimat utama, dan informasi spesifik di bagian teks.

Dalam menggunakan wrap-up strategy, guru meminta siswa untuk melakukan kegiatan-kegiatan berikut dalam kelompok mereka setelah seluruh teks dibaca: menghasilkan pertanyaan untuk mewawancarai satu sama lain, menceritakan kembali apa yang telah dibaca berupa ringkasan; dan melakukan perdebatan pro-kontra tentang topic. Tujuan wrap-up strategy adalah untuk meningkatkan pengetahuan, pemahaman, dan memori dari apa yang dibaca siswa. Pada pertemuan keempat, sebagian besar siswa sudah aktif bergabung dalam kegiatan ini. Bahkan siswa yang memiliki penguasaan kosakata yang kurang termotivasi untuk berpartisipasi dalam menyumbangkan ide. Ini merupakan perbaikan sejak pertemuan sebelumnya hanya siswa yang memiliki penguasaan kosakata yang baik berpartisipasi dalam diskusi kelas.

Dalam strategi MCSR, siswa diminta untuk belajar secara berkelompok. Hal ini dilakukan untuk membuat siswa merasa lebih nyaman dalam belajar. Mereka akan lebih merasa bersemangat dalam belajar kelompok dibandingkan dengan belajar secara individual. Belajar secara kelompok memudahkan siswa untuk belajar mandiri serta berbagi ilmu dengan teman. Sementara itu, dalam proses berinteraksi dengan orang lain, proses belajar berlangsung dalam lingkungan sosial budaya melalui dialog. Hal ini sejalan dengan teori sosiokultural Vygotsky sebagaimana tercantum dalam Graves, Juel, dan Graves (2007), di mana pembelajaran berlangsung di lingkungan yang interaktif. Hal utama adalah bahwa tanpa interaksi dalam rangka membangun makna dan pemahaman, pembelajaran tidak terjadi. Berdasarkan penjelasan tersebut, dialog interaktif antara siswa-guru atau siswa-siswa dalam membangun makna sangatlah penting.

Sebagai tambahan, perbandingan angka persentase dari respon total kuesioner untuk item A, B, C, dan D adalah $58.66 \%$ (berarti sangat setuju), $32.60 \%$, (berarti setuju), $8.74 \%$ (berarti ragu-ragu) dan $0 \%$ (berarti tidak setuju ). Angka ini membuktikan bahwa perilaku siswa menunjukkan perubahan positif dalam pembelajaran membaca menggunakan MCSR dan siswa memiliki pendapat yang positif terhadap MCSR.

\section{KESIMPULAN}

Melihat dari peningkatan nilai post-test siswa di setiap pertemuan, dapat disimpulkan bahwa teknik MCSR efektif untuk meningkatkan kemampuan membaca siswa dalam pelajaran reading. Hal ini dikarenakan MCSR memiliki beberapa keunggulan yaitu

1. MCSR memiliki strategi membaca secara spesifik: preview strategy, fix-up strategy, get-the-gist strategy, and wrap-up strategy.

2. MCSR adalah student-centered learning

3. MCSR berlangsung dalam lingkungan sosial budaya melalui dialog dan belajar berkelompok

Dari hasil kuisioner pun dapat dilihat adanya respon positif dari siswa terhadap teknik MCSR tersebut.

Melihat keberhasilan penggunaan strategi MCSR dalam meningkatkan kemampuan membaca siswa dalam mata pelajaran Bahasa Inggris, penulis menyarankan agar para guru Bahasa Inggris mempertimbangkan MCSR sebagai salah satu 
strategy alternative yang bisa digunakan dalam pengajaran di dalam kelas.

\section{PRAKATA}

Penulis mengucapkan terimakasih kepada beberapa pihak yang terkait dengan penelitian ini:

1. Kop. Wil. VIII Bali Nusra atas pembiayaan penelitian ini (SPP Hibah Penelitian Nomor 1294/K8/KL/2013 Tanggal 4 Juli 2013);

2. Kepala sekolah serta guru Bahasa Inggris SMA (SLUA) Saraswati 1 Denpasar atas kerjasamanya hingga penelitian ini dapat berjalan lancar;

3. Rektor Universitas Mahasaraswati Denpasar serta Dekan FKIP Universitas Mahasaraswati

Denpasar atas dorongan dan semangatnya.

\section{DAFTAR PUSTAKA}

Barnes, Mary. (2004). The use of positioning theory in studying student participationin collaborative learning activities. Paper presented as part of the symposium"Social Positioning Theory as an Analytical Tool"at the Annual Meeting of the Australian Association for Research in Education, Melbourne, November 28-Decmber 2, 2004.

Brown, H. Douglas. (1994). Teaching by Principles: An Interactive Approach to Language Paedagogy. San Francisco: Prentice-Hall, Inc.

Brown, R, Rob Warning, and Sangrawee Donkaewbua. (2008). Incidental vocabulary acquisition from reading, reading-whilelistening, and listening to stories. Reading in Foreign Language. No. 2, 20, pp. 136-163.

Burns, Paul C. et.al. (1996). Teaching Reading in Today's Elementary Schools $6^{\text {th }}$ Ed. New Jersey: Houghton Mifflin Company.

Dogan, B. (2002). The effect of strategy teaching on reading comprehension motivation and retention in cooperative and traditional classeses.Unpublished Doctorate thesis, DokuzEylul University.
Fan, Y.C. (2010). Implementing Collaborative Strategic Reading (CSR) in an EFL context in Taiwan. Unpublished Thesis. Retrieved on June 2012, from http://Ira.le.ac.uk/handle/ $2381 / 434$.

Fitri, A. (2010). The effectiveness of Collaborative Strategic Reading (CSR) on the Reading Comprehension Achievement of the Fourth Semester Students of PGSD Suryalaya, West Java, Indonesia.UnpublishedThesis.Post Graduate Program of UM. Retrieved on june 2012, from http://karyai-lmiah.um.ac.id/ index.php/disertasi/article/view/8238/0

Fraenkel, Jack R and Norman E Wallen. (1990). How to Design and Evaluate Research. New York, NY : MC. Gray- Hill. Inc.

Graves et.al. (2007). Teaching Reading in The $21^{\text {st }}$ Century, fourth edition. USA: Pearson Education. Inc.

Huang, C.Y. (2004). Think to win: An inquiry-based approach via Collaborative Strategic Reading technique to teach reading in a senior high EFL classroom.

Hornby, AS. (2000). Oxford Advance Learners' dictionary of Current English. New York: Oxford University Press.

Kagan, S. (1994). Cooperative Learning. San Juan Capistrano, CA.

Kemis and Tegart, (1990). The Action Research Planner. Civtoria: Deakin University Press.

Klinger, J.K and Vaughn, S. (1988). Using CSR.

Retrieved June 2012, from http://www.idonline.org/id in depth/teaching technique/collab reading.html.

Klingner, J. K., and Vaughn, S. (1996). Reciprocal Teaching of Reading Comprehension Strategies for Students with Learning Disabilities Who Use English as a Second Language. Elementary School Journal.96, pp. 275-293.

Klinger, J.K, Vaughn, S. and Schumn, J.S. (1998) .Collaborative Strategic Reading during social studies in heterogeneous fourth grade 
classroom. The elementary school journal, 99,1, pp. 3-22.

Klingner, J. K., and Vaughn, S. (2000). The helping behaviors of fifth-graders while using collaborative strategic reading $(C S R)$ during ESL content classes. TESOL Quarterly, 34,pp. 69-98.

Klingner, J. K., Vaughn, S., Argüelles, M. E., Hughes, M. T., and Ahwee, S. (2004). Collaborative Strategic Reading: "Real world" lessons from classroom teachers. Remedial and SpecialEducation, 25, pp. 291302.

Klingner, J. K., Vaughn, S., Dimino, J., Schumm, J. S., \& Bryant, D. P. (2001). From clunk toclick: Collaborative Strategic Reading. Longmont, CO: Sopris West.

Laufer, Batia and Jan Hulstijn. (2001). Incidental Vocabulary Acquisition in Second Language: The Construct of Task-Induced Involvement. Applied Linguistics. No.22, 1, pp. 1-26. Oxford University Press.

Masidjo, Ian. (1995). Penelitian Pencapaian Hasil Belajar Siswa di Sekolah Yogyakarta. Kanisius.

Mason, B. and Krashen, S. (1997) Extensive reading in English as a foreign language. System No. 25,1, pp.91-102.

Pitts, M., White, H., and Krashen, S. (1989). Acquiring second language vocabulary through reading: a replication of the Clockwork Orange study using second language acquirers.Reading in a Foreign Language.No.5, 2, pp.271-275.

Slavin, R. E. (1995). Cooperative Learning theory, Research and practice.Boston: Allyn and Bacon.

Walker, B.J. (1992). Diasnostis Teaching of Reading; Technique for Instructional and
Assessment. Secon Edition. New York: Harper Collin Collage Publisher.

Wang, T.H. (2008). The Effect of modified Collaborative Strategic Reading on EFL learners' Reading Comprehension. Unpublished MA dissertation, National Changhua University of Education, Changhua, Taiwan.

Waring, R. and Takaki, M. (2003). At what rate do learners learn and retain new vocabulary from reading a graded reader? Reading in a Foreign Language.No.15, 2, pp.130-163.

Vaughn, S., and Edmonds, M. (2006). Reading Comprehension for Older Readers. Intervention in School and Clinic. No. 41, 3, pp. 131-137.

Zoghi, M. (2002). Building Reading Skills Up at the Tertiary Level.Roshd FLT Journal.No. 78, 69, pp. 27-37.

Zoghi, M., Hazita A. and Tg Nor Rizan, Tg. M. M. (2006). CSR II: An Instructional Technique for Reading Strategies. The Procceding of SoLLs. INTEC.07.Malaysia: Universiti Kebangsaan Malaysia.

Zoghi, M., Ramlee Mustapha, and Tg Nor Rizan, Tg. (2011). The Effects of Modified Collaborative Strategic Reading (MCSR) Intervention on Reading Performance among Freshmen in Iran. Journal Teknologi (56), 23-46. Malaysia: UTM Press. 
